\title{
Private Economy Development in Vietnam: Strengthening Corporate Competitiveness through Corporate Social Responsibility performance
}

\author{
Thi Huyen Sang Pham $^{1^{*}}$ and Thanh Dat $\mathrm{Vo}^{2}$ \\ ${ }^{1}$ Vinh University, 182 Le Duan street, Vinh city, Nghe An province, 460000, Vietnam \\ 2 People's Police University, 36 Nguyen Huu Tho Street, District 7, Ho Chi Minh City, 70000, \\ Vietnam
}

\begin{abstract}
Private economy development in Vietnam is currently considered an important driving force of the socialist-oriented market economy. This is a board topic and involves a lot of content that can be discussed. In particular, increasing enterprise efficiency through the corporate social responsibility performance is considered as a main issue of private economy development in Vietnam. This paper aims to study the theoretical and legal issues of private economy development in Vietnam and the role of corporate social responsibility implementation in private economy development. Thereby, this article clarifies the implementation of corporate social responsibility in Vietnam today, assesses the limitations and thus proposing solutions to increase the business efficiency through corporate social responsibility performance.
\end{abstract}

\section{Introduction}

Corporate social responsibility (hereinafter referred to as CSR) is the commitment of the corporate to contribute to sustainable economic development, through activities to improve the quality of life of employees and their family members, the community and the whole society, in a way that benefits both the business and the overall society development. In another way, in order to achieve sustainable development, a corporate must comply with the standards on environment protection, gender equality, labor safety, equal pay, training and staff development, community development in a way that benefits the company as well as the general development of society and other social responsibilities, through the application of the Code of conduct (hereinafter referred to as $\mathrm{CoC}$ ) and international standards such as SA8000, ISO 14000, ISO 26000 and so on (according to the definition of the World Business Council for Sustainable Development). CSR in Vietnam started to be applied mainly in foreign direct investment enterprises or organizations related to international development cooperation. Especially in the export-oriented footwear and textile production economic regions, where Vietnamese enterprises must know with certainly that in order to export to international markets, it is inevitable to set up the

\footnotetext{
*Corresponding author: sangpth@,vinhuni.edu.vn, sangpham@hotmail.co.uk
} 
integration of CSR into production activities and even raises the CSR issues to the companies' strategic level. However, CSR have not been synchronously applied by both state-owned and private sector businesses. It can be seen that, although corporate social responsibility in Vietnam has been accessed for more than 20 years yet due to various limited reasons enterprises are still hesitant and delayed in formulating an implementation strategy of CSR. The causes which may stem from many different aspects, namely: the limited perceptions and awareness of CSR from enterprises, State and stakeholders; Limitations in the legal system related to CSR, the ineffective management and monitoring of the CSR implementation; the lack of transparency and publicity in businesses operation; lack of support activities from involved individuals and organizations; lack of effective mechanism for resolving complaints, disputes or requests objects are victims or affected by irresponsible acts of CSR; lack of financial resources and material and technical support for businesses CSR implementing and so on.

However, recognizing the existing problems and their causes, many solutions have been proposed to promote and enhance the synchronous implementation of CSR by Vietnamese enterprises, especially the group of Small and medium enterprises which are accounting for nearly $97 \%$ of the number of Vietnamese enterprises. These recommendations and solutions include: improvement of policy and legislation in the implementation of CSR; Strengthening the management role of the state; strengthening the role of the agencies and organizations involved; Strengthening the role of civil society; Develop mechanisms to ensure compliance with the rules of conduct or unilateral commitments DN; Increase the public transparency of businesses by requiring businesses to provide CSR reports or other similar social reports and some other measures to support CSR implementation.

According to the experience of some other countries in the world such as UK, France, India and Canada, it can be seen that the implementation of CSR can be both compulsory and voluntary. This is reflected through clearly defining the economic context, level of thinking and awareness of their country to choose the right direction. From that point of view, perhaps it is necessary to consider starting to apply compulsory CSR in certain groups of businesses depending on their fields of investment and business and from then to replicate and deploy more synchronously in the entire companies in the country when eligible.

\section{Materials and methods}

- Analytical method is used to evaluate and comment on legal regulations, practical situations as the basis for scientific conclusions such as national (and international) regulations on CSR. This method is used throughout the implementation of the research topic;

- The reports of State management agencies on private sector enterprises were used to evaluate the current situation of private sector enterprises development in Vietnam.

- The methods of synthesis, analysis, commenting, survey, evaluation and comparison were used to get a comprehensive perspective on the current situation of CSR implementation, from which could be accordingly drawn the remaining problems, challenges and in order to propose solutions to enhance CSR implementation in Vietnam. 


\section{Current situation of private economy development in Vietnam today and the role of corporate social responsibility implementation in private economy development}

The private economy is an important driving force of the Vietnamese economy. Since the implementation of the renovation policy until now, the Vietnamese Communist Party's awareness and policies on the private economy have been increasingly supplemented and completed. Resolution No.10-NQ/TW of the Communist party of Vietnam dated 3/6/2017 on "Private economy development becomes an important driving force of a socialist oriented market economy" [12], is a new step creating motivation to promote the development of the private economy sector and the whole economy. This helps demonstrating the continuous renewal of the Party's economic thinking to match the practice of the economy development after 30 years of renewal. This resolution has contributed to affirm the important role of the private economy and also stated the general goal including: private economy development must be healthily, efficiently and sustainably and really become an important driving force of the socialist market-oriented economy.

Private economy exists in the forms such as private enterprise, Limited Liability Company, Joint Stock Company and individual business household. Resolution No.10 NQ/TW [12] has set the goal of private sector to develop rapidly and sustainably with high growth in both quantity, scale, the quality and share of the gross domestic product (hereinafter called as GDP). Over the past years, the private sector has played an important role in developing the dynamic economy, contributing to create jobs and improve people's incomes. The private sector has also contributed in making a breakthrough and leading in many new fields of production and business. Therefore, creating all favorable conditions for developing the private economy sector is also releasing of development resources in the society, so that it could possibly help the socialist-oriented market- based economy to maximize its potential.

With the reforms and adjustments of policies and guidelines, the Vietnamese private economy strongly develops in quantity, diversifies types ownership, type of businesses, form non-state enterprises to business households and individual business. The number of newly established enterprises and registered capital tends to increase in the period 2011-2018: Comparing between 2018 and 2011, the number of newly established enterprises increased by 1.6 times, the registered capital increased 2.5 times, and the average registered capital of enterprises increased 1.5 times (9). Thus, 2018 is the year when the number of newly established enterprises and registered capital reached a record of the highest ever. According to official statistics, Vietnam currently has about 600 thousand enterprises, including over 500 thousand private enterprises. Of these, more than $96 \%$ are small and medium enterprises, 2\% medium-sized enterprises and 2\% large enterprises. Private firms create about 1.2 million jobs, contributing more than $40 \%$ of GDP per year.

Private sector development is a factor that not only ensures the maintenance of GDP growth and generates revenue for the state budget, but also participates in solving a series of social issues such as: job creation, hunger eradication and poverty reduction, human resource development and so on. In 2019 private sector continuously maintains a fairy good growth rate, accounting for the proportion of $40-43 \%$, attracting about $85 \%$ of the workforce. The private sector's contribution to the GDP structure is always over $43 \%$ of GDP (compared to the state economy sector $28.9 \%$ of GDP and the foreign direct investment (FDI) sector is $18 \%$ of GDP) $[8,17]$. Trademarks of the private sector have not only been recognized in the domestic market but also in the regional and international markets; there also have been large-scale private sector groups in both capital and high technology. Therefore, there is 
need to pay proper attention to the development of the private economy through a mechanism to enhance business efficiency by implementing corporate social responsibility. Corporate social responsibility (hereinafter called as CSR) is widely recognized from the view of the World Business Council for Sustainable Development: "Corporate social responsibility is the commitment of the enterprise in contribution to sustainable economy development, through compliance with environmental protection standards, gender equality, labor safety, labor rights, fair wages, staff training and development, community development, product quality assurance and so on in a way that benefits both businesses as well as the general development of society" [14]. This concept shows that there are two groups of objects that enterprises must perform main responsibilities including internal responsibilities (for company members, employees, and external responsibilities (market, consumers, environment, community). Thereby, it can be seen that the groups of objects that enterprises must take social responsibility towards the company's members, the environment, social community, localities, with employees, consumers, markets.

Recognizing the importance and significance of CSR, governments are increasingly interested in investing in CSR development, viewing it as part of the functions and tasks of state management. Along with the general trend of developed countries and some other developing countries, CSR has really attracted attention not only to the state, businesses but also to public, the media, and especially the private sector. In the respect, CSR is really meaningful both as a bridge linking the relationships in economic activities together, and as well as a meeting point for countries in the region and around the world that commonly interest in CSR activities. It is shown that a revolution has really begun which marked by the regulatory interest of the state and government and coordination between the state and enterprises. Such cooperation is only possible when the parties both understand and realize the meaning and value of CSR. When enterprises understand the meaning and role of CSR, the state management of CSR implementation will surely be cared more. When businesses are interested in investing and developing CSR not only because of pressure from the public, but also because of the awareness of its roles and meaning, the effect will really be worth the costs that businesses have spent.

The implementation of CSR can be seen as not only benefit enterprises themselves economically but also the society in terms of sustainable development. If enterprises do the business with profits, accordingly bring income and stable life for employees and their families, as well as contribute to building a living environment and ensuring consumers' rights; then surely those things have contributed to creating economic stability of the country. This economic foundation is the basis for creating stability in other aspects, especially in society and thereby political stability. Therefore, it can be seen that, recognizing the meaning, role or in other words, the benefits of caring, implementing and developing CSR is really necessary, which creates a foundation for action and at the same time the solution for enhancing the efficiency of current CSR.

\section{Legal system related to corporate social responsibility in Vietnam}

Corporate social responsibility has been applied in Vietnamese business sector, yet there has not been a specific law that directly govern CSR. It is common understanding that CSR derives in nature from the requirement to comply with minimum legal regulations, then it is possible to go beyond the minimum legal rules, which are the voluntary commitments of the business through the development of codes of conduct or the application of existing ones. Therefore, firstly, it is required that enterprises must strictly follow the legal 
regulation system as hard constraints serving as the basic for well implemented CSR. Besides, there are still soft constraints reflecting in voluntary enterprise commitment known as the $\mathrm{CoC}$ that enterprises must comply with. The legal framework for CSR activities in Vietnam includes labor law, environmental protection law, consumer protection law, corporate law and other relevant laws. In addition, the system of international conventions is also an important factor as the basis for the regulation of CSR-related issues.

In terms of the general theoretical basis of CSR, the system of governing legal documents includes: legal documents that create corridors, general legal documents, recording the constitutional principles as well as relevant laws ensuring the implementation of CSR includes: Constitution 2012; Civil Code 2015, Enterprise Law 2020; Commercial Law 2005; Investment Law 2020; Ordinance on Grassroots Democracy 2007, Criminal Code 1999, amended and supplemented in 2009; Law on handling administrative violations in 2012, Law on Civil Procedure 2004 amended and supplemented in 2009; Civil code 2015, Criminal Procedure Law 2015 (amended 2017) and other documents guiding the implementation;

Regarding the law on corporate responsibility in protecting employee rights: Labor code no.45/2019/QH14 on November 20,2019; Law on trade union no.12/2012/QH13 dated on June 20, 2015; Law no.58/2014/QU13 dated on November 20,2014 on social insurance; Law no.25/2008/QH12 dated on November 14, 2008 on health insurance; Law no.46/2014/QH13 dated on June 13, 2014 on amendments to the law on health insurance; Law no.84/2015/QH13 dated on June 25, 2015 on occupational safety and hygiene;

Corporate responsibility in protecting employee rights are regulated by a systems of sublaws such as: Decree no.05/2015/ND-CP dated on January 12, 2015 on defining and providing guidance on the implementation of a number of contents of the Labor code; Decree no.148/2018/ND-CP dated on October 24, 2018 on amendments to the government's decree no.05/2015/ND-CP dated January 12, 2015 on elaborating of some contents of the Labor code; Decree no.88/2020/ND-CP dated on July 28, 2020 on elaborating some articles of the law on occupational safety and health on compulsory insurance for occupational diseases; Decree no.90/2019/ND-CP dated on November 15, 2019 on stipulating region-based minimum wages applied to employees working under labor contracts; Decree no.38/2020/ND-CP dated on April 3, 2020 on elaborating to law on Vietnamese guest workers; Decree no.28/2020/ND-CP dated on March 1, 2020 on administrative penalties for violations arising from labor, social insurance and sending Vietnamese workers abroad under contracts; Decree no.24/2018/ND-CP dated on February 27, 2018 on providing for settlement of complaints about and denunciations if labor, vocational education, Vietnamese guest workers, employment, occupational safety and hygiene;

Regarding the law on the responsibilities of enterprises in protecting consumers' rights: Law no.59/2010/QH12 dated November 17, 2010 and Law no.43/VBHN-VPQH dated on December 10, 2018 on protecting consumer's rights 2010; Competition Law no.23/2018/QH14 dated on June 12, 2018; Law on Product and goods quality no.05/2007/QH12 dated on November 21, 2007; Law on Measurement no.04/2011/QH13 dated on November 11, 2011; Law on Food Safety no.55/2010/QH12 dated on June 17, 2010; Law on standards and technical regulations no.68/2006/QH11 dated on June 29, 2006; Law on Advertising no.16/2012/QH13 dated on June 21, 2012; Law on Prices no.11/201 2/QH13 dated on June 20, 2012.

In order to provide detailed guidelines on above-mentioned law, there have been many sublaws such as: Decree no.35/2020/ND-CP dated on march 24, 2020 on elaborating on several articles of competition law; Decree no. 181/2013/ND-CP date on November 14, 
2013 on elaboration of some articles of the law on advertising; Decree no.99/2011/NĐ-CP of Vietnam government dated on October 27, 2011 on detailing and guiding a number of articles of the law on protection of consumer rights; Decree no.15/2018/ND-CP dated February 02, 2018 on elaboration of some articles of the law of food safety; Decree no.98/2020/ND-CP of Vietnamese government on handling administrative violations in trade, production, trafficking, fake, prohibited and consumer rights protection; and other documents guiding the implementation; Decree no.177/2013/ND-CP dated on November 14, 2013 on detailing and guiding the implementation of a number of the law on price; Decree no.149/2016/ND-CP dated on November 11, 2016 on amending and supplementing a number of articles Decree no.177/2013/ND-CP dated on November 14, 2013 by the government providing guidance on implementation of a number of the law on pricing

Regarding laws related to CSR in environmental protection: The State has issued legal documents such as the Law on Environmental Protection 2014; Law on special consumption tax in 2008; Law on Environmental protection tax in 2010; Law on Environmental protection tax in 2010; Law no.82/2015/QH13 dated on June 25, 2015 on natural resources and environment of sea and islands; Law No.17/2012/QH13 dated on June 21, 2012 on water resources.

In order to provide detailed guidelines on above-mentioned law, there have been many sublaws such as: Decree No.155/2016/ND-CP dated November 18, 2016 on penalties for administrative violations against regulations on environmental protection; Decree No.19/2015/ND-CP dated February 12, 2015 on detailed implementation of a number of articles of the Law on Environmental Protection 2014; Decree No. 18/2015/ND-CP dated February 14, 2015 on environmental protection planning, strategic environmental assessment, assessment environmental impact and environmental protection plan; Decree No.38/2015/ND-CP dated 24/4/2015 on waste and scrap management; Decree No. 29/2008/ND-CP dated 12 May in March 2008 of the Government on regulations on industrial zones, export processing zones and economic zones; Decree No. 164/2013/NDCP dated November 12, 2013 of the Government amending and supplementing a number of articles of the Decree No.29/2008/ND-CP dated March 14, 2008 of the Government regulating industrial zones, exporting processing zones and economic zones; Decree No. 80/2014/ND-CP dated August 6, 2014 of Government on drainage and wastewater treatment; Circular No.35/2015-TT-BTNMT dated 30/06/2015 on environmental protection Economy, industrial parks, export processing zones, high-tech zones;

Regarding international regulations, Vietnam has ratified many international conventions related to CSR as follows

In term of the international convention on environment protection, Vietnam has joined the international treaties on the environment such as the Convention on the Law of the Sea, the Vienna Convention on the protection of the ozone layer, the Convention on controls, transportation across border and destruction of hazardous wastes (Basel), Convention on international trade of endangered wild fauna and flora species, Convention on biological diversity...

Referring to the protection of workers 'rights, Vietnam has ratified the ILO International Labor Organization's conventions on basic principles and rights at work such as Convention No, 6 on children's working nighttime in industrial areas, Convention No. 14 on the application of weekly breaks for industrial facilities, Convention No.27 on the marking of weights on large parcel of ships, Convention No.45 on the use of women underground in mines, Convention No. 80 amending the final provisions, Convention No,81 on labor inspection in industry and commerce, Convention No.116 Amending Final Clauses, Convention No, 120 on hygiene in commerce and offices, Convention No. 124 on medical examinations for youth working underground in mines, convention No.155 on 
occupational safety, labor hygiene and working environment, Convention No. 123 on minimum age to work underground in mines, Convention No.100 on equal remuneration between male and female workers for work of equal value, Convention No.111 on discrimination in employment and occupation, convention No. 182 on the prohibition and urgent action of eliminating the worst forms of child labor, Convention 138 on minimum age for employment, Convention 144 on tripartite consultation to promote the implementation of international labor regulations.

In relative to the international convention on protecting the rights of consumers, Vietnam has officially signed the General Agreement on Tariffs and Trade 1994 of the WTO, Guidelines on the Protection of consumers of UN 1999, the SPS Agreement on animals and plants quarantine measures, which specifies the rules for the application of the provision in the 1994 GATT Agreement relating to the use of sanitation of animal and plant measures, in particular the provisions of Article XX (b)).

Regarding the guidelines, international code of conduct, there have been many international code of conduct guiding the CSR performance. However, these code of conducts have just been applied by mostly foreign direct invested or exporting companies but not private sector business if not compulsory. These well-known code of conducts are compose of OECD Guidelines on multinational corporations, The United Nation Global Agreement (UNGC), ISO 26000 series of standards, ISO9000 standard set, ISO 19011 series standards, ISO 14000 series standards, ISO 22000 series of standards, ISO 26000 series of standards, OHSAS 18000 standard and so on.

\section{The current situation of implementing corporate social responsibility in Vietnam}

In the national development roadmap, Vietnamese state wants to maintain social orientation, supporting disadvantaged groups in the commune, redistributing the rich and the poor and supporting the community through policies, laws and other benefit programs. Therefore, the economic and social role of enterprises has been proved to be an effective factor in participating in rich and poor redistribution programs as well as supporting disadvantaged groups in the society as above mentioned. This is the premise for the implementation of CSR in the future, although it has not been clearly defined. Until the 1990s, Nike Company in Vietnam, which was doing business and developing, was found to violate the rights of employees, caused a trend of the domestic and international press and media to complain about a call a Nike product boycott. The general accusation of the media here is that Nike has not only failed to build a working environment that ensures conditions for employees but also even creates a working environment that is hazardous to human health. After that, of course, Nike had to change its business strategy in a timely manner to better fit with social requirements, by publicly announcing its customers and suppliers Nike's Social Responsibility policy [2]. At the same time, there are many enterprises that mainly are foreign-invested companies, also revealing stories of employees' violation of working time and rest time. Even, there were a number of enterprises with foreign investment (mainly from China, Taiwan, and Malaysia) [2,5,14], which were reported the situation of exploitation of employees' labor force and even punishment abusing to discipline employees. By 1996, in the US, the media reported on forced working conditions that Honduran workers suffered in the Kathie Lee Gifford garment factory [2,14]. Since then, there are continual federal investigations on forced environmental work across the United States, as well as the inevitable consequences of the need to develop and strictly implement a CSR. 
The story of Nike, Kathie Lee Gifford, and a number of other companies, not only happened in the US or Vietnam, but also popular in many other countries especially exporting countries where there are factories, labor market with inexpensive costs derived from developing countries including Vietnam. Therefore, following Nike, a number of other multinational companies have developed a CSR policy closely linked to their products and services, which is reflected in the quality policy commitment to the community and employees and recognized in the public business strategy with the mass media. At this point, the story of CSR was just an impractical theory especially when there was even a high consensus of business that CSR implementation could be the main reason for the costly investment. However, despite that fact, the general trend was raised to gather the supports from the community, society, employees and consumers as well as other individuals and organizations for CSR implementation. On the other hand, the trend of boycott businesses that do not have or even have the weak CSR activities due to the lack of humanity in the operation process was also raised at the same time.

CSR in Vietnam started to be applied mainly in foreign direct investment enterprises or organizations related to international development cooperation. Especially in the exportoriented footwear and textile production economic regions, where Vietnamese enterprises must know with certainly that in order to export to international markets, it is inevitable to set up the integration of CSR into production activities and even raises the CSR issues to the companies' strategic level. During the years of exporting goods to markets such as Europe, America, Japan and so on, a lot of Vietnamese consignments have been returned due to failure to meet international standards $[5,14]$, especially CSR standards. Therefore, there were a great effort of the Vietnamese State in establishing and developing international cooperation to exchange experiences and train international exporting skills for Vietnamese enterprises. Typically in 2006, the UK Department for International Development supported Vietnam in providing the introduction of a national program on worker protection, occupational health and safety. This project was sponsored by the Vietnam General Confederation of Labor, the Vietnam Chamber of Commerce and Industry and the Vietnam Cooperation Alliance. The project purpose was to provide the guiding on International Labor Organization Standard 155 on occupational safety and health [5,14]. Another cooperation, for example between the Industrial Development Organization UNIDO and Vietnamese government, which focused on training and supporting SMEs in promoting friendly production environment in order to achieve sustainable economic development and encourage SMEs to perform CSR [5].

In 2007, since Vietnam jointed WTO and became more and more integrated with the world market, CSR has become important in the domestic market and businesses. Accordingly, there were an increasingly requirement for the exporting enterprise's product to meet international certificates and standards such as Euro gap (Certificate of Product Quality in the European Market), Haccap (safe and hygienic products quality), Halal (Certificate to allow product using in international Muslim community) and so on. Following that, social and labor standards as well as anti-corruption efforts were a common topic of discussion by the forum for stakeholders. At this stage, social and labor standards began to be applied in the Corporate Code of Conduct which was regarded as the core element of CSR. On the other hand, the process of organizing and implementing CSR was initially proved that corruption was one of the biggest barriers in implementing CSR. Since then, the topic of anti-corruption was also considered the main duties to be fulfilled in order to prepare for the construction and implementation of the CSR regime in Vietnam [5; 14].

In fact, some companies have taken seriously the SA 8000 standard, ISO 14000, ensuring the hygiene and safe production, typical example was Unilever Vietnam, Bao Viet group and Hoa Sen metal production. Some businesses built long-term strategies to more fully 
implement their social responsibilities both in term of environmental protection and emission limitation such as Samsung Group and DaiKin Group. However, the implementation of CSR has been mainly concentrated in foreign direct invested enterprises, while its was clearly not found in private enterprises due to limitation of awareness, capacity, experience, and finance $[9,14]$. In addition, some companies actively participate in charitable activities, typically as the Lotus Group and FPT Group. Lotus Group is a major manufacturer of corrugated iron and sheet steel, located in Ho Chi Minh City, with annual revenue of about VND 10,000 billion and over 3,000 employees. This enterprise always spends $3.5 \%$ of its annual profit on charity (approximately VND 11 billion, on average); Similarly, FPT is Vietnam's largest joint stock company in the information technology and education sectors, with a turnover of US $\$ 1.2$ billion and over 15,000 employees. FPT's philanthropic and charitable activities can be mentioned as a variety of: sponsoring 2-3 billion VND per year to organize an online math playground for high school students nationwide, attracting over 10 million turns of student's participants, or building social "For the Community" networks $[3,6,14]$

Organizations of civil society in Vietnam has been formed actively and provided practical contributions, for example the Vietnam Chamber of Commerce, Industry and the industrial association such as Textiles, Exporting seafood and Association of financial investors. The role of such organizations and associations are responsible for consulting, supporting businesses operation, production and promoting investment. Furthermore, these organizations could either help providing assistant in the development and establishment of industrial codes of conduct, organization of training courses, or advocating for the implementation of standards and regulations of social responsibilities especially for employees, consumers and environmental protection. In addition to the establishment of civil society, one of the positive factors of stakeholders in the business community, which are commonly known as non-governmental organization (NGOs) and business associations, activists, media, and educational institutions, can effectively help businesses in increasing CSR awareness and integrating CSR in corporate strategy by using a variety of measures to disseminate CSR on the one hand and on the other hand to provide business incentives to foster commitment to CSR.

Currently, there are about 1,000 international NGOs and business associations operating in Vietnam, with supporting amount of more than 300 million USD in 2019 [9]. Supporting activities of these organization have been implemented across 63 provinces, with particular emphasis on the poor and remote areas as follow the economic development priorities and orientations, especially poverty reduction and sustainable development. The help of nongovernmental organizations is not only financial support but also technical support such as experience and technology transferring, training and so on. In the field of CSR, some typical NGOs can be seen such as Vietnam Chamber of Commerce and Industry (VCCI) with propaganda, training, consultation and awarding activities for enterprises showing good social responsibility in terms of environment and community. The United Nations Industrial Development Organization (UNIDO) is also a typical NGO in its efforts to promote CSR in Vietnam recent years. Besides VCCI, there are also others NGOs industry associations in specific field such as Vietnam Textiles and Apparel Association, Vietnam Cotton and Fiber Association, Vietnam Banking Association and so on, which on the one hand have strengthened CSR in its own sector, on the other hand, incorporated the activities of VCCI and other international organizations to promote CSR. Further, NGOs have also made efforts in coordinating to implement a number of activities such as propaganda, training sessions, sharing experiences between businesses and stakeholders, organizing dialogue on solutions to build CSR regimes in Vietnam and sponsoring CSR projects. 
Products of NGO's activities can be mentioned as follows: Global Compact Network Vietnam; Vietnam Business Association Initiative and Business Office for Sustainable Development, Vietnam Network of NGOs and Climate Change. These NGOs together with corporates, government and other related parties have made certain contributions in bringing CSR into the working program of Vietnamese enterprises under various forms including finance and techniques supporting, and at the same time encouraging and motivating many businesses to participate in CSR implementation in recent years. In addition, many awards for CSR have been awarded to honor businesses with good CSR implementation. CSR award is organized by the Vietnam Chamber commune of Commerce and Industry awarding to enterprises with good CSR regime in terms of labor environment, which was carried out from 2005 to present. Up to now, about 30-40 enterprises are honored as socially responsible enterprises every year [8].

Thus, it can be seen that CSR appeared in Vietnam quiet early yet received official implementation attention over the past two decades or so. There have been many activities implemented yet still lack of synchronization from all stakeholders. There has been interest from the state, government and regulatory agencies, however, there is still a lack of specific and clear policies and legal mechanisms. The implementation of corporate social responsibility will bring efficiency to business development in particular and the private economy in general. For that reason, it is required that State, enterprises as well as other related organizations need to pay attention and coordinate together to promote the quality and efficiency and synchronous practices of CSR activities of enterprises in general and private sector in particular.

\section{The restrictions in the formulation and implementation of corporate social responsibility in Vietnam}

CSR has been implemented by Vietnamese enterprises in practice, but has not yet to meet the setting forth requirements. The majority of Vietnamese enterprises still have not paid attention to CSR. Violations against content subject to the regulation of corporate social responsibility have still occurred in many places by many type of the enterprise. In particular, the unilateral commitment of enterprises has just considered voluntarily without the methods or sanctions to ensure binding on corporate social responsibility.

Firstly, the perception and awareness of enterprises on corporate social responsibility has still been limited in various views of the business, the State and stakeholders. It is proved in fact that the quality of corporate social responsibility implementation in recent years has not been effective deriving from the different level of perception of businesses as well as stakeholders about its significance and importance. Therefore, it is important to raise awareness of the business, states and stakeholders on the importance role of social responsibility of enterprises.

Secondly, corporate social responsibility has not yet uniformly regulated, but scattered in many different documents. In terms of the "hard" law, the number of documents governing the contents of corporate social responsibility could be found up to hundreds of legal documents, not including international law. In term of "soft" law construed as the selfcommitment on CSR, the number of codes of conduct as well as legal standards have been also blooming in businesses, industries, regions. Accordingly, the overlapping of legal system on CSR has led to either the inefficiency in CSR performance or misunderstanding the priority position of regulations when applied in enterprises. In addition, it can be seen that the current Vietnamese legal provisions have just only met the most basic conditions 
for stakeholders, and have not really kept up with the higher requirements specified in the legal standards, international law or codes of conduct on CSR.

Thirdly, the state management of corporate social responsibility has still ineffective. After being fully aware of the issues of corporate social responsibility, surely it is required to consider professional qualifications in state management. However, at present, there has not been any management agency in charge of the operation of CSR, of which the main reason is because CSR has not yet clearly defined. On the other hand, the construction of personnel or specialized agency on CSR will lead to the ability contrary to the requirements of reforming and streamlining the current state apparatus administrative management.

Fourthly, the problem of lack of publicity and transparency in business operations with community society is also a major obstacle. Lack of publicity and transparency is both the source of many problems and the basis for the germination of bad sides that hinder the businesses development in their efforts to set up CSR. Therefore, it is necessary to build a mechanism ensuring that businesses are open and transparent in matters of corporate social responsibility.

Fifthly, corporate social responsibility has not yet been effectively supported by other individuals and organizations such as non-governmental organizations, organizations representing interests of stakeholders, industry associations and so on. These organizations will be the most effective factor in the process of managing the implementation of corporate social responsibility. However, due to many different reasons including weak capacity, lack of finance, lack of management and supervision, lack of legal status, these organizations are not really effective in supporting CSR.

Sixthly, it is necessary to consider a mechanism for resolving complaints and disputes for those who are victims or affected by corporate social irresponsible violation. The method of settlement by the way of the Court, recently, has been shown ineffectiveness when the people or the "weak" parties have not fully exercised their power.

Finally, the problem of lack of financial resources and technical support for businesses is amongst the reason to delay the development of CSR in Vietnam, which is even more a prominent problem of private sector enterprises. Corporate social responsibility requires businesses to build for themselves not only a set of codes of conduct but also a system of physical equipment to serve the implementation of that code of conduct. However, financial constraints as well as weak support from the State and other organizations are also major obstacles for businesses in performing CSR.

It can be seen that corporate social responsibility since its inception in Vietnam has still been a reluctant choice for businesses, except for some special enterprises due to compulsory commitment in performance of the code of conduct. If the fully awareness of the role and meaning of the implementation of corporate social responsibility are raised, it will certainly help improving the position of business, thereby achieving the goal of attaining more profit.

The process of bringing corporate social responsibility from awareness to implementation of regulations synchronously in private sector enterprises today is actually facing many difficulties and obstacles. Existing and limited issues, as well as those barriers have actually delayed the company in respecting and fulfilling its legal obligations and responsibilities for the rights of workers, consumers and society. Therefore, it is most urgent requirement now is to find solutions and ways to overcome these difficulties in order to improve the efficiency of corporate social responsibility performance in Vietnam. 


\section{Solution to enhance corporate social responsibility in Vietnamese private sector business}

Firstly, the organization of training courses, propaganda to raise awareness of stakeholders about the meaning and role of CSR for environment is also a measure that needs to be addressed today, in order to increase awareness about CSR. Implementing CSR requires full awareness and proper content and meaning, contribution CSR with businesses, with the object to be protected and the entire economy. Therefore, it is necessary to further strengthen the forms of communication and dissemination of CSR in enterprises, for the employees' collective and the social community, through many different channels such as training, seminars, and media. To propagate the concept of CSR through educational tools and training such as seminars and training courses not only for entrepreneurs, employees, consumers, but also for the parties concerned as well as future generations to understand the importance of CSR. Along with the content of CSR awareness training, it is necessary to consider to include CSR content in school education and training programs, even from smaller educational levels to educate each person. It is because CSR is ethical by nature, thus, raising awareness of CSR should be initiated very early.

Secondly, it is necessary to either issue a specific law or guidance on CSR practices for Vietnamese businesses or incorporate mandatory regulation on CSR implementation into the corporate law. As the result of this provision, CSR performance must be shown in the code of conduct of all kind of enterprises regardless of types, industries, occupations and fields and purpose of business operation. CSR implementation must be regulated mandatorily and by law.

Thirdly, strengthening the State's management role is necessary to foster CSR in Vietnam currently. It is required that the management, evaluation and monitoring mechanism must be implemented synchronously from the central to local levels and grassroots levels. That means it is necessary to build a more specialized state agency in the field of CSR. Therefore, it is necessary to choose the solution between maintaining the current organizational structure of state management agencies and adding additional CSR management function only or building a specialized agency for managing CSR activities in order to be more focused and professional.

However, it is necessary to consider that this agency will be a state management agency or an agency with certain independence from the state to avoid negative aspects, lack of objectivity in the management process, detrimental to enterprises. CSR is an issue dealt with a minimum of responsibility for compliance with legal regulations. Yet, there is no limit for specific content in CSR due to the characteristics of the ethical and humanistic categories. Therefore, considering building a specialized agency is a necessary solution to avoid increasing the burden on other specialized management agencies while ensuring more expertise. That agency may be state or non-state, but it is necessary to have government agency support in enforcing it.

Fourthly, one of the solution for the best practice of CSR is increasing corporate public transparency by requiring social responsibility reports or other similar social reports. Reporting of corporate CSR activities plays an important role in fulfilling the obligation to provide information to stakeholders, creating a deeper understanding of the activities that businesses have done to get results of CSR implementation. In short, the content of the CSR report can include topics such as the content of the CSR such as responsibility to company members, employees, environmental protection, effectiveness in relation to consumers and community, social contributions and so on. One more thing to note, is that these reports must be verified by an independent, professional and reputable third party to verify the accuracy and truthfulness of CSR reports provided by the company. 
Like other financial reporting activities, if enterprises are required to provide CSR reports, they will inevitably involve reports of accounting and social auditing. This requires staff working in the CSR field to have expertise in both CSR and finance and business. In Vietnam, there is no legal framework and guidance on this responsibility to manage and organize the implementation, and help the community to monitor in practice. Reference to non-financial reports according to the laws of the French and Canadian governments or the guidance on how to develop GRI-reporting reports under the provisions of ISO 26000 standards is also one of the useful experiences for Vietnamese enterprises to develop CSR reports $[7,15]$.

Fifthly, together with the role of state agency, it is vita duty to strengthen the role of relevant agencies and organizations. Parallel to state management activities, it is necessary to manage, monitor and evaluate the optimal effective CSR implementation in the non-state sector. It is necessary to combine with strengthening the role of civil society and other organizations and individuals involved in promoting the quality of CSR. Promoting the positive role of organizations of civil society is not only to complement for the role of state, buts also to supervise state and businesses in CSR activities and thus to limit the selfinterested behavior, abuse of state authority or behavior contrary to the culture and ethics of the enterprise. The supervision of the community and society is proved by reports that enterprises must complete, which are reports on social accounting, social audit and social reporting. Currently, in Vietnam there have not been a legal framework for the responsibility to develop the above types of reports for enterprises. The provision of responsibility to provide the aforementioned types of reports aims to reinforce the awareness of both enterprises and the community about CSR implementation, and at the same time provide a specific legal basis for assessing the level and quality of CSR implementation.

Sixthly, in the OECD guidance for multinational companies, the establishment of a network linking national CSR points of contact is also seen as an effective solution and can be considered as a model for building an independent agency in charge of CSR in Vietnam. The purpose of engaging in network building of national communications under the guidance of the OECD is to share business expertise to manage, resolve issues of CSR. The OECD guidelines cover the concept of "national contact point" (NCP), in which all OECD member countries must establish this NCP in the domestic system. NCP is responsible for promoting the properly directing for businesses and solve problems on CSR under the guidance of the OECD. The interested party may file a complaint with the NCP on the violations of CSR of the OECD in the country. The NCP is seen as an off-state mediation mechanism. NCPs in different countries work together on issues and report regularly. The legal nature under international law is the responsibility between states to establish NCP which directly related to state responsibility. However, it is necessary to take measures to motivate enterprises, especially small and medium enterprises to join this NCP's network for continuous feedback. That also means how this responsibility regulation can be enforced, because if there is no enforcement mechanism, the effect will be difficult to achieve.

Finally, in order to have a well-functioning CSR regime, it is necessary to have specific facilities and financial support to encourage enterprises to commit and willing to implement CSR. It is required that the State budget programmer must refer to allocation criteria and specific limits for the construction of the conditions of facilities, technical infrastructure (information technology is applied) to serve incident implementation, management and supervision of State agency and organizations involved in the implementation of CSR. In addition, for businesses, there should be financial support regulations or financial incentive 
mechanisms governed by law or policy to stimulate demand, and help businesses pay attention to promote CSR quality.

It can be seen that spending part of the operating expenses of the budget which is also the revenue from the tax sources of enterprises to invest in CSR in fact very worthy and appropriate. It is seen as an activity of state management, investment and risk reduction, avoiding violations that involve many times higher costs to overcome.

\section{Conclusion}

As in the foreword of the Earth Charter (EC) stated: "we must decide to live with a sense of global responsibility, defining ourselves in the earth community as well as our local community. We are citizens of different countries and of a world in which the local and the global are connected. Each of us shares responsibility for the present and future humanity of our families and even greater world we are living in". As global citizens, enterprises also play the role of global corporate citizen, which must have a sense and responsibility to contribute to the community and society in order to share obligation with living present and future.

In the process of international integration, a variety of companies worldwide have recognized the social and economic benefits of CSR policies and measures on the rise. Commitments to CSR go beyond the desire to increase profits, provided that the company is fully aware of its employees, customers, communities and the environment. Many enterprises have used CSR as a new business direction when realizing that it can help enhance the role of managers, improve financial status, improve employees motivation, promote customer loyalty and corporate reputation toward society. Therefore, it is necessary to construct and promote CSR implementation, not only for the community where businesses operate but also for the whole country and more broadly, for the global and the world overall. Thus, it is crucial to enhance CSR in private economy sector in order to strengthen corporate competitiveness in the modern world today.

\section{References}

1. Chan, Anita, (ed.) Labor in Vietnam. Vol. 31. Institute of Southeast Asian Studies, 2011.

2. Dang, Giang, and Minh Trí Phạm. Corporate Philanthropy and Corporate Perceptions of Local NGOs in Vietnam. Asia Foundation, 2013.

3. Hamm, Brigitte. Pacific News 38 (2012): 4-8.

4. Hoang, Huong T., Trang T. Nguyen, and Jerry F. Reynolds. International Social Work 62.3 (2019): 1075-1087.

5. Ministry of Planning and Investment, Report of private economy development, phase 2010-2018 (2019)

6. Nguyen, Minh, Jo Bensemann, and Stephen Kelly. International Journal of Corporate Social Responsibility 3.1 (2018): 9.

7. OECD (2011), OECD guidelines for multinational enterprises

8. OECD (2016), Private Sector Engagement for Sustainable Development: Lessons from the DAC, OECD Publishing.

9. Sang, Pham Thi Huyen. Corporate social responsibility and sustainable business development: 27. 
10. Tien, Nguyen Hoang, Dinh Ba Hung Anh, and Nguyen Minh Ngoc. Corporate Social Responsibility and Environmental Management 27.2 (2020): 694-705.

11. Trinh Duc Chieu, Vietnam's private economy: growth dynamics and new expectations, Vietnam finance journal, January 2020

12. Van Thanh, Phan, and Szilárd Podruzsik. Management (18544223) 13.4 (2018). 